\title{
Looking Back to Look Forward: After Forty Years of Alma Ata Declaration, What are Our Priorities?
}

\author{
Sunitha Srinivas ${ }^{1,2}$ \\ ${ }^{1}$ Project Lead, SPEAK-Health Systems, Institute of Public Health, Bengaluru, Karnataka, INDIA \\ ${ }^{2}$ Visiting Professor, Rhodes University, Grahamstown, SOUTH AFRICA.
}

Public health history is marked by several momentous events, and $12^{\text {th }}$ September 1978, was one of those. Delegation from 134 countries, 67 international organisations, and many non-governmental organisations joined the World Health Organisation and UNICEF at the International Conference on Primary Health Care at Alma-Ata, Kazakhstan, USSR from $6^{\text {th }}$ to $12^{\text {th }}$ Sep 1978 and this culminated in the Declaration of Alma Ata. ${ }^{1}$ The zealous goal of 'Health for All by 2000' based on primary health care (PHC) was the driving force of this Declaration. Amongst various aspects, the Declaration stated that it "Relies, at local and referral levels, on bealth workers, including physicians, nurses, midwives, auxiliaries and community workers as applicable, as well as traditional practitioners as needed, suitably trained socially and technically to work as a health team and to respond to the expressed bealth needs of the community".

The ambitious concept found certain areas of growth and was adopted partially in the Selective Primary Health Care approach. However, overall the PHC concept was overshadowed and the role of tertiary care systems continued to dominate. The emergence of the Ottawa Charter in Canada as part of the first International Conference on health promotion continued to adopt relevant aspects of the Declaration. The Commission on Macroeconomic in Health, Millennium Development Goals as well as the Commission on social determinants of Health continued to pave the path of public health globally.

Now forty years later, on $25^{\text {th }}$ and $26^{\text {th }}$ October 2018, WHO is celebrating the event. ${ }^{2}$ The Global Conference on Primary Health Care in Astana, Kazakhstan, is designed to revive the focus on PHC so that global efforts in working towards universal health coverage and the Sustainable Development Goals, two key aspects of high importance in the current public health scenario, is consolidated.

Though we may not have participated actively as pharmacists in this community-centred approach, forty years later, when this event is being celebrated globally, it is time for us to become active participants. We can't ask for a better time and space for a change where the profession contributes visibly. One of the guiding documents is from the International Federation of Pharmacists which provides the Good Pharmacy Practice in developing countries. ${ }^{3}$ While the clinical training for present and future pharmacists are geared towards enhancing the professional's contributions, it is also time to take stock of current challenges and opportunities to contribute in strengthening health care systems from the grass root levels at the PHCs. A community-centered approach that encompasses prevention of diseases, health promotion, empowering individuals and families at the grass root levels, is equally important.

Moving forward requires us to look back and reflect on what we have achieved so far, and how we intend to be game changers in becoming team players to implement the National Health Policy $2017^{4}$ with a crucial focus on Universal Health Coverage.

Wish you all well while you each reflect on your current roles and future trajectory, so we join as team members for a common National and Global goal of strengthening primary health care.

\section{REFERENCES}

1. http://www.who.int/publications/almaata_declaration_en.pdf

2. http://www.who.int/primary-health/conference-phc

3. https://www.fip.org/files/fip/Statements/latest/Dossier\%20 003\%20total.PDF

4. http://cdsco.nic.in/writereaddata/National-Health-Policy.pdf
DOI: 10.5530/ijopp.11.3.24

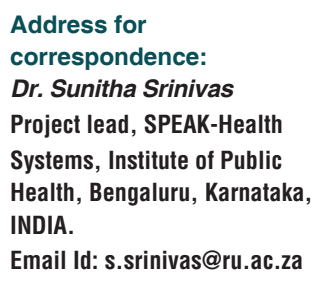

Address for correspondence: Dr. Sunitha Srinivas Project lead, SPEAK-Health Systems, Institute of Public Health, Bengaluru, Karnataka, INDIA.

Email Id: s.srinivas@ru.ac.za

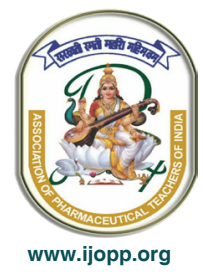

